\title{
The portrayal of Africa and Africans in the book of Jeremiah
}

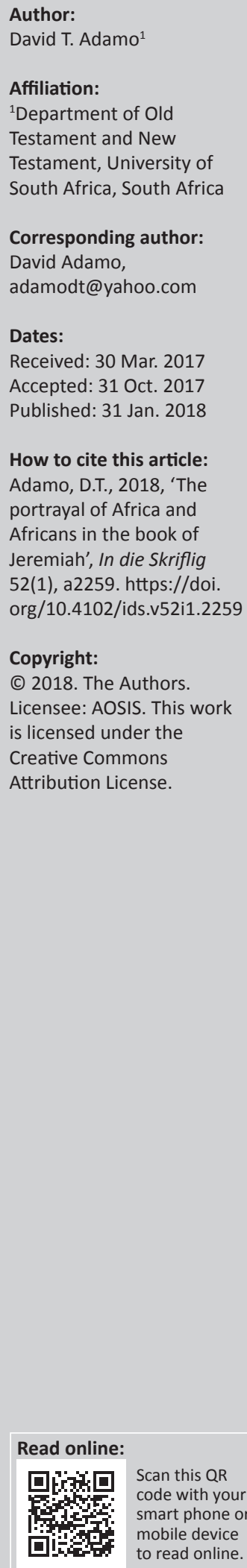

Since the 1980s, many Jeremianic scholars have spent much time on the study of the various contentious issues in order to resolve them. However, there has been no unanimous agreement yet. One of these contentious issues is the relationship of the prophet Jeremiah to ancient Africa and Africans which is the main focus of this article. The author of the book Jeremiah made references to Ancient Africa and Africans about 53 times in the Septuagint, and 67 times in the Masoretic Text. This indicates that the prophet Jeremiah is very familiar with ancient Africa and Africans. Using a historical-biographical and theological method of reading Jeremiah, this article examines the portrayal of ancient Africa and Africans in the book of Jeremiah. It is also part of an investigation of the African presence in the Old Testament which, to Africans, is an important moral and self-lifting scholarly exercise. It is also gratifying information in itself to know that Africa and Africans have participated in the drama of redemption which has not been recognised as such by either Eurocentric scholars or by the majority of Africentric scholars themselves. While in the Pentateuch references to Africa and Africans appear more than 577 times, in the Major Prophets there are about 180 references. What this means is that not only the author of the book of Jeremiah, but biblical authors in general are very familiar with ancient Africa and Africans, and deliberately took time to identify them. The continued recognition by scholars and non-scholars of Africa and African presence in the Bible has great implications for Christianity in Africa.

\section{Introduction}

The book of Jeremiah belongs to the Major Prophets. Some rabbinic authorities place the book of Jeremiah as the first of the prophets instead of the book of Isaiah (Petersen 1998:95-128). The book of Lamentations, which is usually ascribed to the prophet Jeremiah, follows. Many traditions include the apocryphal books of Baruch and the Epistle of Jeremiah in their canon (Petersen 1998:95-128).

Since the 1980s, the study of biblical prophecy and prophetic books has been going through a paradigm shift (Nissinen 2009:103-111). The book of Jeremiah appears to be exceptional because of so many contentious scholarly issues on which the Jeremaianic guild does not agree, even today. These include the composition of the book of Jeremiah, Baruch, the scribe, the Deuteronomic edition of Jeremiah, the relation of the Masoretic Text (MT) to the Septuagint (LXX) and the feminist imagery in Jeremiah (Allen 2008:4; Avigad 1986; Carroll 2008:198; Chase 2011:9; Galvin 2011:125; King 1993:93-99; McKane 1986:xlix-1; O'Connor 2012:267; Shule 2013:131; Weems 1995:94). ${ }^{1}$

The above contentious issues have led to different methods of reading the book of Jeremiah such as a historical-biographical and fable of compositional readings (Hill 2002; Parke-Taylor 2000; Sharp 2003), rhetorical-critical readings (Hayes 2002; Lundbom 1999:68-84; Muilenburg 1968; Van den Eynde 2001) and theological readings. I prefer and will employ a combination of the historical-biographical and theological readings because of their many advantages. A theological approach makes the desire to render Jeremiah's divine symbol more palatable, meaningful and serviceable to modern needs. It also helps in decoding the basic 'thematic message of the book of Jeremiah' (Adamo 2014:508). The historical-biographical reading makes sense if employed (Carroll 2004; De Jong 2011:483-510; Glatt-Gilad 2000; Holladay 2003:185-189; Lundbom 1999). In other words, it supports the acceptance as a historical person and the book represents the work of the person of Jeremiah. Moreover, the people of African ancestry, mentioned in the book, are also viewed as historical persons rather than fictional. The theological reading has the advantage of assisting the readers to make sense of the chaotic situation concerning the composition, the 1.Because the focus of this article is not based on these contentious issues, it is enough to just mention them.

Note: This article was originally presented at the IOSOT Conference at the University of Stellenbosch on 2-5 September, 2016. 
difference between the LXX and MT and the feminist imagery in the book.

The chaotic order in the book of Jeremiah is still a problem. However, when one understands that the book of Jeremiah is a product of a fiercely troubled international time, the chaotic order in the book is not surprising. It means that Jeremiah is familiar with international powers such as Babylon and Africa (Egypt-Cush). It also gives evidence to the fact that the prophet is very familiar with the black skin colour of the Africans, because, by the 8th century and up to the 6th century BCE, Africans (Cush and Egypt) became the hope of ancient Israel against the Assyrian and Babylonian powers (Adamo 2010:473-501). That is why the prophet was able to use the well-known metaphor of African skin colour and leopard spots as valuation for Israel in Jeremiah 13:23.

\section{Identification of Africa and Africans in the book of Jeremiah Cush, Cushitic and Cushi}

Cush was mentioned several times in terms of geographical location and as persons' names in the book of Jeremiah. Although debates still exist among scholars as to whether Cush, as a geographical location, refers to Africa or Mesopotamia, I am of the opinion that where Cush is used in the entire Old Testament, it refers to nowhere but Africa and persons of African ancestry (Adamo 1986; 2005:14).

In the Major Prophets, the terms used to refer to Africa and Africans appear more than 180 times. Cush appears also as a geographical location. Cushi was also used in terms of names of people such as in the book of Jeremiah 36:14 where the ancestors of Yehudi, the prince who read Jeremiah's script to King Jehoiakim, were traced to Cushi. Ebed-Melech, the Cushite who delivered one of the greatest prophets, the prophet Jeremiah, from death was also mentioned in Jeremiah. He was specifically described as a Cushite. It is quite interesting that, while Cush or Egypt occurs 53 times in the LXX, in the MT they occur 67 times in the book of Jeremiah. This indicates that the prophet Jeremiah is very familiar with Africans (Cush or Egypt) (Galvin 2011:125). ${ }^{2}$

\section{Egypt and Egyptians}

Africa and Africans were mentioned more than 1417 times in the entire Bible. Of this, Egypt (Mitsrayim) was mentioned more than 740 times in the Old Testament (Adamo 2005:26-36). In the Pentateuch, references to the words Egypt and Egyptians occur more than 288 times. Egypt and Egyptians appear about 152 times in the book of the Twelve. It also appears in Isa (40 times), in Jeremiah (61 times), in Ezekiel (47 times) and Daniel (4 times). Egypt and Egyptians as well as Cush and Cushites were always mentioned together in the Old Testament, because they both belong to the African nation. Egypt belonged to the northern part of Africa and to a region of the Ancient Near
East. This term indisputably refers to Egypt as a country in Africa and also to the people of Egypt in Africa. Ancient Egypt and Egyptians were Africans and, in fact, black Africans and not Europe and Europeans as some have alleged.

Despite the fact that the ancient Egyptians saw themselves as Africans, some Western biblical scholars have tried to deAfricanise them, thus making Ancient Egypt a Near Eastern or European nation. ${ }^{3}$ The Egyptians themselves considered Africa and not Asia as their place of origin. The inscription of Queen Hatshepsut attested to the fact that they originated from Punt to which they made several expeditions (Keener \& Usury 1996:61). Many other scholars such as Glenn Usry and Craig Keener have argued for the Africanness and blackness of ancient Egypt and the Egyptians. According to them, 'most Egyptians were black by any one's definition' (Keener \& Usury 1996:61).

\section{Pharaoh}

Pharaoh was a title of Egyptian rulers mentioned about 213 times in the Pentateuch. The pharaohs were Egyptians and Africans except possibly those of the time of the Hyksos and other invaders of Egypt who forced that title on themselves. In Egypt 'Pharaoh' means 'Great House' - it originally refers to the royal palace (Wilson 1951:102). It was only later, especially in the Eighteenth Dynasty, perhaps sometimes during or prior to the reign of Thutmose III (1479-1425 BCE) (Alexander \& Baker 2003:630), that Pharaoh began to be applied to the ruler's person and a symbol of authority that could not be challenged in Egypt. From the time of Shoshenq 1 (945-924 BCE), the term was sometimes included in the titularies of royal inscriptions, and later in the Twenty-second Dynasty (945-715BCE). By the 7th century, it was conjoined with the proper name (Alexander \& Baker 2003:631).

Pharaoh is also one of the terms used in the book of Jeremiah. It was used 5 times in Isa, 11 times in Jeremiah and 12 times in Ezekiel. Why mention Africa and Africans so frequently? Perhaps because the children of Israel and their ancestors sojourned in Africa for 450 years, according to Exodus.

\section{Reason for the frequent mentioning of Africa and Africans in the book of Jeremiah}

\section{Familiarisation}

It is very likely that the authors, editors and redactors of the book of Jeremiah are very familiar with Africa and Africans. They may not only be familiar but possibly lived in Africa. They may have been Jews who had lived in Africa for a long time.

3.A few years after Count Volney's trip, Napoleon's invasion of Egypt followed in 1798 (Volney 1991:3-19) and thus the opening up of Egypt for archaeological discovery. The massive discovery in Egypt and the development of the New Hamite Hypothesis, The massive discovery in Egypt and the development of the New Hamite Hypothesis, which was bent on debasing Negroes, could not permit Egyptologists to talk of the possibility that Negroes had developed the civilisation of the Nile Valley. For example, as early as 1810, Bluemenbach (1865), a pioneer in racial classification, tried to prove that the ancient Egyptians-African Cushites were not Negroes. However, severa Africanists (Copher 1985; Diop 1974; Jackson 1932; Rogers 1982), after an examination of Egyptian Nile Valley representations, have held very strongly that the Egyptians and the people of the Nile Valley are of one race: Negroes or Blacks. 
As discussed above, the Egyptians used the word Kush to refer to limited areas of the places beyond Wawat and later extended it to the whole south land up to the Cape of Good Hope. According to Lepsius, the Kushite originally came from Asia during the reign of Pepi I (2000 BCE) and eventually built settlements throughout Africa down to the eastern coast nearly to the Cape of Good Hope (Baldwin n.d.; Maspero 1968:488). Further, the inscription of Ameni, written during the reign of Sesostris I, mentioned several expeditions to the land of Kush and the overthrew of his enemies, 'the Abominable Kash,' obtaining tributes and going as far as the 'horn of the earth' (Breasted 1906:251; Budge 1976:534-535). During these expeditions, Negroes were taken captive and sent to Egypt as slaves and servants (Breasted 1906:251; Budge 1976:534-535). According to George Rawlinson, who agreed with Maspero and Budge, Puntites are to be found not on the Arabian, but on the African side of the gulf where the present Somali land is located (Rawlinson n.d.:72). David O'Connor (1982) of the University Museum at the University of Pennsylvania in the USA, described the Puntites as follows:

Typically, the men have dark reddish skins and fine features; characteristic Negroid types ... and the Egyptians have always visited Punt from time immemorial. The relationship has been of trade rather than political or subordination. (p. 917)

The earliest record mentioning the Puntites was in the Palermo stone, referring to them as bringing produce from Punt (O'Connor 1982:917). We also have records of the Egyptian expedition to Punt under the command of Henu to search for precious stones and balsam (Breasted 1906:208210; Budge 1976:538-571). The inscriptions at the Temple of Karnak gave the account of Thutmose III's expedition to Punt and the list of the places conquered: Kash (23), Wawat (24) and Punt (195). The fact is that the Puntites and the Egyptians were well known to each other. Any idea that the Egyptians isolated themselves from Africa, south of the Sahara, should be totally rejected.

Nehesi means the southern black people or Negroes and the Egyptians used the term to distinguish themselves from the people of the south of Egypt who were also Negroes, but lived in the north. The earliest reference to Nehesi is also in the Palermo stone when King Snefru, the father of the great pyramid at Giza's builder, claimed to have destroyed a people called Ta-Nehesi and captured 7000 prisoners and 200000 cattle and sheep (Adamo 1986: 42). The second appearance is in the longest narrative inscriptions and the most important historical document from the Old Kingdom the inscription of Una at Abydos. Una, the governor of the south, recorded that the armies he led against Asiatics contained the southern Negroes (Nehesi) from Medjay, Yam, Wawa and Kaam (Breasted 1906:142; Pritchard 1969:227228). A.J. Arkell (1961:59) maintained that Amenemhat I, the first ruler of the Twelfth Dynasty was a son of Nehesi. Up to the Sixth Dynasty, probably under Pepi II in the 'Admonition of the Egyptian Sage,' the southern black people (Nehesi) were a danger to Egypt (Pritchard 1969:445). What I am trying to say is that these people, the Nehesi, Puntites, Kushites and others from the south eventually ended up in
Egypt and dwelt there. Although they were not Egyptians, they were Africans. Therefore, a large number of Africans south of the Sahara and their ancestors lived in Egypt by the time of Ramses II. I believe very strongly that they were the greatest number of the people referred to as the 'mixed multitude' (Adamo 2012:67-78)

By the 8th century BCE, there was a great interaction between Egyptians and ancient Israel. If the authors of the Old Testament refer to Cushites and Egyptians about 57 and 70 times, it means that ancient Israelites are, no doubt, very familiar with Africa and Africans.

\section{Identity, respect and human dignity}

As said above, 'Cush' is an important way of identifying those of African ancestry by describing them according to the colour of their skin. The word Cush in Modern Hebrew still means black. ${ }^{4}$ In Isaiah 18:1 the river in Africa is described as river Cush, that is, river Nile. In Isaiah's woe oracle against Africans, the river Nile is also described as river Cush, that is, river 'black'. Likewise in Isaiah 20:3-5, Africans were described as Cushites, that is, black people.

The implication of the above is that the authors were not only very familiar with African land, but also had tremendous respect for the people and the land. That is probably why they were very interested in describing the people and their land accordingly. For example, the prophet Isaiah described them as follows:

Ah, land of whirring wings beyond the rivers of Ethiopia, sending ambassadors by the Nile in vessels of papyrus on the waters!

Go, you swift messengers, to a nation tall and smooth, to a people feared near and far, a nation mighty and conquering, whose land the rivers divide. (Is 18:1-2 - New Revised Standard Version [NRSV])

Why would the biblical authors of the Old Testament be so enthusiastically interested in African people and their land to be personally identified? The mentioning of Africa and Africans so frequently demonstrates, according to them, the great respect in the biblical times. ${ }^{5}$

\section{Jehudi [the African Prince] reading Jeremiah's scroll (Jr 36:14, 21, 23)}

In the fourth year when the arrogant and evil king, Jehoiakim, succeeded his father Josiah, who was a reformer, the word of Yahweh came to prophet Jeremiah to put his prophecies into writing. He employed a secretary (Baruch), dictated the words of the Lord to him, and he put it into written form (Jr 36:2-4). After Baruch had completed the writing, Jeremiah sent him to read it in the temple during the day of fasting when people throughout the land assembled in the temple - probably due to some

4.I visited Israel in 1981 for an archaeological excavation and was the only black person on the team from Baylor University, Waco, Texas, USA. Israeli boys and girls pointed at me and said, 'Cush, Cush'.

5.The prejudice towards black people and their humiliation are a recent phenomenon and therefore unbiblical. 
national distress or emergency in December 604 BCE. During what might probably be the most memorable day of Baruch's life, he read Yahweh's words, dictated to him by the prophet Jeremiah, in the temple. Although there is no record of any reaction to the words read, one will probably be right to infer that the people were greatly moved. Micaiah immediately reported the matter to the princes (Jr 36:11-13) who were anxious to hear the words of the scroll themselves probably because they could not believe that a man who was banned from the temple and almost killed could have written such a thing. The princes sent 'Jehudi, the son of Nethaniah, son of Shelemiah, son of Kushi' to bring Baruch and his scroll (Jr 36:14). However, when they heard the words and ascertained that they were Jeremiah's words, they were greatly distressed and prepared to consult the king immediately. Knowing what the reaction of the king would be, they advised Baruch and Jeremiah to hide.

After the words had been reported to King Jehoiakim, he sent 'Jehudi, son of Nethaniah, son of Shelemiah, son of Kushi' (כושי) to bring the scroll and read it to his hearing. For the third time, the scroll was read. However, after 'three or four columns' were heard, the king, instead of reacting with reverence like King Josiah, in fury 'cut them off with a penknife' and burnt them in the fire (Jr 36:23). He went further to order the arrest of Baruch and Jeremiah, but 'the LORD hid them' (Jr 36:26).

In this account, the writer of Jeremiah 36 has a list of the important personalities involved. Among the important participants identified personally is 'Yehudi ben Nethaniah ben Shelemiah ben 'Kushi' (Jr 36:14, 21, 23). There are several unusual features about the personal identification of Yehudi. It is very unusual and remarkable that Yehudi's ancestry was traced to the third generation. Literally, his name means 'Jew'. However, his great-grandfather's name, Cushi, means 'black'.

However, a careful examination of the role he played shows that he was probably the most trusted and 'respected man on the scene' (Rice 1975:107). That was probably why he was called upon by the king's ministers and the king himself at the time of such a serious threat and impending crisis (Jeremiah's letter). It is also possible that he was the only one among the king's ministers 'who transcended party strife' (Rice 1975:107). During the discovery of the temple scroll in the days of Josiah (621 BCE), Shaphan, the secretary of state, read the newly discovered scroll which led to the national reformation. The only logical conclusion for that is that Yehudi was not only of African ancestry, he was probably one of the highest and most educated royal state officials (Harrison 1973:20). ${ }^{6}$ This conclusion is strengthened if one notices that out of so many officials present, he was the only one asked to read such an important and sensitive document.

6. Harrison (1973) is probably right when he says that Yehudi must have been a man of importance. Thompson $(1980: 625)$ recognises him as one of the state officials.
Calvin also infers from his genealogy that Yehudi was a man of some pre-eminence (Thompson 1950:339).
This can also be supported by the fact that the business of writing and reading belonged to the professionals in those days (Holladay 2003:185-189). It should also be added that the writer and the final editor of the book of Jeremiah wanted to demonstrate why Africans were so greatly respected throughout ancient Israel. That is probably because of their wisdom.

\section{The image of Africa and Africans in the book of Jeremiah They are portrayed as instruments of salvation}

The words that are mostly used for salvation in the Old Testament are מלט aישע פלט. The word salvation and its derivatives are used about 353 times in the Old Testament (Harris, Archer \& Waltke 1981:928). The word שעי itself occurs about 143 times in the hiphil which basically means 'to save,' 'to free,' 'to help,' and 'to make spacious' (Friedrich 1970:970). In the niphal it means a space is given to the one who is confined. The stem in most cases points to some personal relationships through which deliverance, help and salvation comes in favour of a person who is in a difficult situation (Friedrich 1970:970; Harris et al 1981:973). The Hebrew word means to be saved, be delivered, give victory, be safe and to take vengeance or preserve, rescue or defend a cause.

The nature of salvation in the Old Testament is historical. The actual goal of Yahweh's actions in history is revelational, that is, for him to be known. In other words, revelation itself is historical. God's special saving act from all eternity in the Old Testament is based on the actual historical experience of deliverance from Egyptian bondage, the sea of reed, the Canaanites in the wilderness, the Assyrians, the Babylonians, the Africans and other nations who desired to destroy them. The experience of Yahweh's act of deliverance left its mark on the whole existence of the Israelites and upon every part of the Hebrew Bible. It was preached, recounted in songs and also re-enacted in Passover rituals (Ex 12:1-20; Dt 6:20-24; Ps 44:1, 78, 105-106, 136). As Yahweh used foreign nations such as the Assyrians, the Babylonians and the Persians for punishment and salvation, he also used Africa and Africans in history for the purpose of this act of deliverance. Jeremiah recounted this over and over.

\section{Africa as a place of refuge or deliverance in the book of Jeremiah}

What is important for the purpose of this article is that the narrator, be it J, E, P or D, made Africa the setting of the story and that Africans (Egyptians) were important characters through which the salvation of Yahweh was brought. Again, what I think is an important fact to be taken seriously is that Egypt or Africa provided the background for deliverance in Exodus. It will be correct to say that real salvation experience for the Israelites as a nation began in Africa. Egypt taught the Israelites how to trust Yahweh for deliverance from the hands of enemies (Ex 14). Jeremiah 
(Jr 7:22, 25; 11:24; 16:14; 23:7; 32:21) made several allusions to bringing Israel's ancestors out of Egypt bondage.

\section{The African military might (Jr 46:9)}

The prophet Jeremiah recognised the military might of Africans and portrayed them as such. After the collapse of the Assyrian Empire and the death of King Josiah (609 BCE), Africa reasserted her dominion over the Syro-Palestinian people and forced Judah into a state of vassalage. During the encounter between the Africans and the Babylonians in the Battle of Carchemish in 605 BCE, the prophet Jeremiah composed a poem (Jr 46:1-12) either as a prediction or in celebration of the victory of the Babylonians over the Egyptian army under Pharaoh Neco (Green 1971:186; Hyatt 1956:1105).

The majority of scholars accept the authenticity of this oracle against foreign nations in Jeremiah 16:1-12. In fact, according to Hyatt (1956:1105), this oracle has a greater claim to authenticity than any other in the oracular collection of Jeremiah. Its language attests to this (Hyatt 1956:1105). Eissfeldt (1965:363) was sceptical even though he accepted the possibility of its Jeremianic material.

A notable feature of this oracle is the employment of 'speech forms which are common in the holy war'. There appear 'summons to battle' and the 'command to flee'. Jeremiah 16:2 was a preface providing the background or the occasion for the poem. Perhaps when the prophet Jeremiah heard of the defeat of the African army at the battle of Carchemish, he was deeply moved and he composed the poem in Jeremiah 2:3-17 (Green 1971:185).

This poem is also regarded as unsurpassed in its vividness and power by any other poem in the book of Jeremiah. The address falls into two strophes (Jr 3-6 and 7-12; Green 1971:185). In both strophes the scene is described in a lively manner: in the first strophe (Jr 3-6) the African armies advance to the battle when the officers issue their sharp orders, then panic and attempt to flee. Their destruction is set forth in short sentences. In the second strophe (Jr 7-12), the prophet taunts Pharaoh Neco for his great pride and courage and then shows the inevitable collapse of the cavalry, chariots and infantry. Despite the re-enforcement of the powerful armies of the Africans (Kush and Put are described as gibborim and the Ludim), all were destined to perish, because it is the judgement of Yahweh (Keil 1950:181-82). The description of Kush and Put as giborim is significant. Perhaps it shows that the Egyptian people were depending on them and the Hebrews recognise their might (Keil 1950:231).

The above passage, like others already discussed (Is 18, 20, $30: 1-2 ; 31: 1,3)$, is also another evidence of the degree of Israelite military and political dependence on African nations. It also represents the high degree of the prophetic battle to counteract such military and political dependence on the African nations. This passage also makes clear the reason for Israelite military and political dependence. Ancient Israelites recognised that these African nations (Ethiopia, Put, Egypt and Lud) were great warriors and were exceptionally good in handling shield and bow. The prophets (Isaiah, Ezekiel, Amos, Jeremiah) would not have spent so much time prophesying vehemently against these African nations and their military men. Randall Bailey (1991:165-184) recognises this fact when he argues rightly that the degree of the reliance of Israel on African military protection was responsible for the extremism and bizarre quality of some of the prophets' actions and speeches against the African nations.

\section{Africa and Africans became the hope of Israel (Jr 26:20-21).}

Military dependence on Africa is vivid as described not only in the book of Jeremiah, but also in the other books of the Old Testament such as Hosea, Isaiah, and Ezekiel. According to Hosea, 'Ephraim has become like a dove, silly and without sense; they call upon Egypt, they go to Assyria' (Hs 7:11 - NRSV).

Oh, rebellious children, says the Lord, who carry out a plan, but not mine; who make an alliance, but against my will, adding sin to sin;

who set out to go down to Egypt without asking for my counsel, to take refuge in the protection of Pharaoh, and to seek shelter in the shadow of Egypt;

Therefore the protection of Pharaoh shall become your shame, and the shelter in the shadow of Egypt your humiliation. (Hs 7:11 - NRSV)

The above passages demonstrate beyond any doubt that ancient Israel depended on Africa and Africans, especially Egypt. This is not the only time when Africa has been a place of refuge for ancient people. As early as 3000 BCE the Mesopotamians came to Africa for refuge and for trade in gold in dust (Adamo 1986:49; Pritchard 1969:268-269). Abraham went to Egypt during a famine to prevent starvation (Gn 12). Joseph and Jacob also were in Egypt to preserve the family (Gn 43:1). Hadad, the Edomite prince, went to Egypt for safety and eventually married the Pharaoh's daughter (1 Ki 11:18-22). When Jeroboam rebelled against his father, he fled to Egypt. When the prophet Uriah prophesied the destruction of Jerusalem and King Jehoiakim sought to put him to death, he fled to Egypt. During the destruction of the northern and southern kingdoms of Israel, many fled to Egypt, including Jeremiah who was forced to go to Egypt.

\section{Africa and Africans as an instrument and object of judgement}

Africa and Africans became the stage against which the prophet proclaimed judgement and salvation to Israel. The prophet Jeremiah and Yahweh's judgement of Africa (Egypt and Cush) can be found in the following passages of the book of Jeremiah: 43:11, 13, 27,44;14:12; 46:2, 14. According to the prophet, the Lord will attack Egypt and will bring to the Egyptians death for whom death is destined; captivity to whom captivity is destined; a sword to whom sword is destined (Jr 43:11). He will demolish the sacred places and burn down the temple (Jr 43:13). 


\section{Jeremiah portrayed Africans as having a high sense of moral judgement and courage (Jr 38:7-10).}

The prophet Jeremiah was delivered by a man of African ancestry, Ebed-Melech (Jr 38:7-10; 39). Zedekiah, Josiah's son, was given the charge to lead his nation. However, King Zedekiah was a man unwilling to learn either from the past or from Jeremiah's strong warning that Yahweh was against Jerusalem and that they should surrender to the Babylonians. Soon Zedekiah, probably influenced by his nobles, revolted and Jerusalem was again under siege in 588 BCE. When the siege was temporarily lifted on the approach of the Egyptians (Jr 21:1-10; 34:1-22; 37:1-10), the false prophets interpreted the lifting of that siege as a sign of peace for Jerusalem. However, Jeremiah accepted the siege as God's judgement and interpreted it as temporary. He therefore counselled submission to the Babylonians.

At that time (588 BCE) when any criticism or opposition to the policy of the militant group of nobles, which was determined to carry on the revolt, was considered treason, Jeremiah continued to preach submission to Babylon and the destruction of Jerusalem. During this period, Jerusalem was dominated by militant nobles who considered Jeremiah to be anti-Judah. As Jeremiah was leaving the city (probably to attend to some family business), he was arrested and charged with treason. The nobles demanded that Zedekiah put him to death. Although Zedekiah was friendly with Jeremiah, he did not want to offend the militant nobles. He evaded his responsibility by leaving the whole matter to the nobles to do as they saw fit: 'He is in your hands', King Zedekiah answered. 'The king can do nothing to oppose you' (Jr 38:5). Consequently, the nobles made use of the king's evasion of responsibility and threw the prophet into a cistern to die (Jr 38:6).

At this critical moment when Jerusalem was under the Babylonian siege and Jeremiah was between life and death, a man of African ancestry called Ebed-Melech, whose name literally means 'king's servant', made his appearance. When Ebed-Melech, the African, heard of this murderous act, he immediately sought King Zedekiah who was at the Benjamin gate of the city. While the king was probably settling some legal matters or busy overseeing the preparation for the defence of the city, Ebed-Melech confronted him. EbedMelech not only informed the king about the fate of the prophet, he also charged the people who were responsible for such an act with the great crime of attempted murder (Jr 38:8-9). This action was a risk for Ebed-Melech.

Although King Zedekiah had evaded his responsibility when the aggressive nobles demanded Jeremiah's death from his hand, this time the challenge of Ebed-Melech's courage and sense of right made him act swiftly to save Jeremiah. The king put Ebed-Melech in charge of the men who were to rescue Jeremiah (Jr 38:10; Rice 1975:97). Ebed-Melech, the African, got rags from the storeroom, carefully and gently let them down to the cistern and instructed Jeremiah: 'Put the rags and clothes between your armpits and the ropes' ( $\mathrm{Jr}$ 38:12). So Ebed-Melech rescued one of the greatest Old Testament prophets. When some scholars examined 'EbedMelech's courage, dispatch, compassion, and his ability to bring out the best in one of the kings of Israel', they considered this story in Jeremiah 37:7-13 as 'one of the fairest stories in the Old Testament' (Smith 1929:28). 'Moved to save the life of another and acting without calculation or counting the cost, an unknown black man emerges from obscurity to immortality' (Rice 1975:97). Sometime after the prophet was rescued, he sent some words to Ebed-Melech (Jr 39:15-18), promising that he will survive the fall and also be saved from those seeking his life.

As far as the racial identity of Ebed-Melech is concerned, scholars do not have any problem identifying him as a black man or as a man with black African ancestry. However, his position in Judah during Zedekiah's time is greatly debated. On the basis of the fact that Ebed-Melech was designated as Saris, several scholars have concluded that he was 'a eunuch' keeping King Zedekiah's wives (Keil 1950:111-112). However, others have seen him as either one of the royal officials or courtiers (Hyatt 1956:1075; Green 1971:171; Thompson 1980:639). There are several reasons that make it more probable that Ebed-Melech was one of the highest royal officers and not a eunuch as some have maintained. Israelite law prohibits a eunuch from their congregation (Dt 23:1; Lv 21:17-21). It seems unlikely that Zedekiah would have placed his troops under Ebed-Melech's command if he had been a eunuch. If Ebed-Melech had been a eunuch, Jeremiah would probably have condemned him according to Israelite law.

\section{Africa as valuation for Israel (Jr 13:23)}

Admittedly and at a glance, Jeremiah 13:23 looks as if the prophet Jeremiah had a great prejudice against the Kushites (Africans) because of the English translations. Below are the various English translations:

King James Version (KJV)

'Can the Ethiopian change his skin or the leopard its spots? Then may you also do good, that are accustomed to do evil.' Revised Standard Version (RSV)

'Can the Ethiopian change his skin or the leopard its spots? Then may you also do good, who are accustomed to do evil.' New International Version (NIV)

'Can the Ethiopian change his skin or the leopard its sport? Neither can you also do good, that are accustomed to doing evil.'

New Revised Standard Version (NRSV)

'Can Ethiopians change their skin or leopards their spots? Then also you can do good who are accustomed to do evil.'

All the above translations are virtually the same. What is very unfortunate is that the two major translations in the two major Nigerian languages (Yoruba and Ibo) follow the English translation verbatim giving the impression that there is deep prejudice against black people. This is an example of the degree to which such translations have misled the world. 
The temptation is for one to interpret it as such as some Western exegetes who have a deep prejudice against black African people will normally interpret it. For example, McKane (1963:1143) sees the Cushi of 1 Samuel 18 as black African Negro slave. Hammershaimb, Harper, Mays, Ullendorf, and others also think that the Kushites in Amos 9:7 were compared with Israelites, because Israelites knew the Kushites who were dark-skinned and uncivilised people coming from a despised nation called Africa. According to them the children of Israel knew Cushites as slaves (Hammershaimb 1970:134; Harper 1915:19; Ullendorf 1968:9). According to Stulmann, this is not such a negative verse, but a poem which discusses how Judah is so adamant in rebellious ways. A change in Judah's policy of apostasy is as unlikely as a leopard changing its spots and a black man changing his skin colour (Stulmann 2011:132).

Jeremiah 13:23 has been the subject of debate as to the passage's positive or negative intention. None of these eminent commentators speaks about the unthinkable nature of the claim. They did not discuss why the example is chosen by Jeremiah. What appears to suggest the negative interpretation of this passage is the stress of the use of 'can' or 'able' in the translation which does not really appear in Hebrew version of the passage. However, it is important to note that the Hebrew version uses an interrogative he together with the imperfect of יהפך as the verb in the first clause which is also understood in the second clause. Because there is no Hebrew word for 'can' or 'able' in both clauses, one will expect the interrogative he to be translated as 'would' instead of 'can.' Bailey (1991:165-184) thinks that the translation should then be: 'Would the Cushites change their skin, or the leopard his spots? So also you who have learnt to do evil could do good.' Unfortunately, this translation retains 'Cushites' which is the transliteration of the Hebrew word Cushi. However, as the word Cushi means 'black persons' from Africa, I think the most appropriate translation should be 'Would black Africans change their skin, or the leopards their spots? So also you who have learnt to do evil could do good.' This translation is in full accord with the basis of Jeremiah's charge, that is, the people of Judah are learners of evil and that black Africans and the leopard have learnt the advantages of being who they are (rulers of territories, awesome to their neighbours with great respect from them). So, also those who live the lives of sinning have learned the advantages of being sinners. To the prophet Jeremiah and his audience, it is unthinkable that black Africans would want to change the way they look (Adamo 2014:500530; Bailey 1991:171). The prophet was telling Judah to use black Africans as a yardstick for assessing themselves or, as Dunston (1974:47) puts it, 'it proves beyond a doubt that Black Africans will desire to be white because it is unnatural' (cf. Adamo 2014:500-530).

\section{The implications for the church in Africa}

What are the implications of the fact that Africa and Africans have been mentioned so many times in the Pentateuch and Prophets, and in the Writings?
It shows that Africa and Africans hold a central position and importance in the life and history of ancient Israel and the Bible, particularly in the book of Jeremiah. Africa and Africans contributed to the religious, political and cultural life of ancient Israel. Is it not possible that the concept of monotheism in the religion of Yahwism could have originated from Africa? Is it not possible that the idea of the monarchy in ancient Israel originated from Egypt or Africa? Is it not possible that the large number of similarities in the cultural life of ancient Israel and Africa is the result of Israel's exposure and interaction with Africa? Why are the people of the continent of Africa described as chronically religious? Idowu (1960:vii), in the subtitle of his book Olodumare God in Yoruba Belief, described them as follows: 'IN ALL THINGS ... RELIGIOUS'.

Africa and Africans participated in the drama of redemption not as slaves, as many Euro-American scholars have alleged in their biblical exegesis. Ancient Africans are people of high esteem as indicated in this article: the Cushites - the Egyptians - became the hope of Israel; Ebed-Melech and Jehudi were respected people of African ancestry.

It shows that the Bible is not a foreign book to Africa and Africans as some political agitators or anti-colonialists in Africa have claimed, and therefore Christianity is not a foreign religion in Africa.

It means that the terms Hebrews and Israel refer to some multiethnic group of people and those multi-ethnic people have an African strand The identity of the mixed multitude that went out with the Hebrews in Exodus 12:38 as containing mostly Africans, if not Africans exclusively, is discussed (see Adamo 2012:67-78).

It means that without the participation of Africa and Africans in the life and history of ancient Israel, the Bible would have not been in the shape it is according to the biblical authors, editors and redactors. If Africa and Africans appear about 1417 times, more than any other nation except Israel, some importance must have been attached to them.

Finally, it relieves Africans from the inferiority complex that has been imposed upon them by the Euro-American slave masters. For example, in the days of slavery in America when the question of converting African slaves to Christianity arose, it was resolved that there was no need, because they were less than human beings and therefore lacked souls to convert (Johnstone 1973:218). If the slave owners had been aware of the role of Africa and Africans in the Bible, perhaps they would have not been treated as slaves. Perhaps, the dignity of Africans and all humankind would have been recognised if the Bible had been searched and interpreted without bias against Africa and Africans.?

7.In 1442, when Antonio Gonsalvez and Nuno Tristan brought some Africans and some gold dust to Pope Martin V of Portugal, the Pope conferred upon Portugal the possession and sovereignty over all countries from Africa to India, because, possession and sovereignty over all countries from Africa to India, because,
according to him, the heathen nations had no right to possess anything on earth for all the treasures belong to the people of the Kingdom (Adamo 1985:78-79). 


\section{Conclusion}

From the above, one can appreciate all the frantic efforts of Jeremianic scholars to understand both the person of Jeremiah and his book. The many shifts in the historical events during the period of Jeremiah's ministry possibly affected the many shifts in literary style and perspective throughout the book of Jeremiah. It also suggests that prior to its final redaction by the biblical editors, its composition may have been the combined effort of the prophet, Jeremiah, and his friend and scribe, Baruch (Matthews 2012:143).

The continuous identification of the people of African descent as 'Cush' is an important way of identifying those of African ancestry by describing them according to the colour of their skin. It possibly shows the ancient Israelites' appreciation of Africans. If the word Cush in modern Hebrew still means black, one will be correct to translate Cushites as black Africans in Jeremiah 13:23.

My examination of the biblical texts that mention Africa and Africans (Cushites and Egypt) has shown that the ancient biblical world was not prejudiced towards black people in their midst. Prejudice towards people with black skin colour is certainly post-biblical and alien to ancient Israel. Africans or Cushites were never racialised by the authors of the Bible (Sandler Jr. 2006:401). It has been demonstrated in this article that the author or authors of the book of Jeremiah, particularly 13:23, and the entire Old Testament did not despise the people called 'Cushites' in a manner consistent with a racialist paradigm of the modern society. Instead they were viewed as people who are faithful, (Ebed-Melech in Jr 38:6-14; 39: 16-18), strong and reliable (Tirhakah), and people worthy of great esteem (Adamo 1986:167; Matthews 2012:143; Sandler Jr 2006:401; Thompson 1980:639).

The use of black Africa as valuation for Israel's action demonstrates the great value attached to them during the biblical period. The frequent mentioning of Cushites and Egyptians demonstrates the deep knowledge, familiarity and respect the biblical and ancient people, in general, have for them.

\section{Acknowledgements Competing interests}

The author declares that he has no financial or personal relationships which may have inappropriately influenced him in writing this article.

\section{References}

Adamo, D.T., 1985, African American heritage, Texas Press, Waco, TX.

Adamo, D.T., 1986, 'Africa and Africans in the Old Testament and its environment', PhD dissertation, Baylor University, Waco, TX.

Adamo, D.T., 2005, Africa and the Africans in the Old Testament, Justice Jeco Publishers, Benin City.

Adamo, D.T., 2010, 'Teaching the history of Ancient Israel from African perspective', Old Testament Essays 23(3), 473-501.

Adamo, D.T., 2012, 'A mixed multitude: An African reading of Exodus 12:38', in A Brenner \& G.A. Yee (eds.), Exodus and Deuteronomy, pp. 67-78, Fortress Press, Minneapolis, MN.
Adamo, D.T., 2014, 'Reading Jeremiah 13:23 in an African context,' Journal for Semitics 23(2), 500-530.

Alexander, D.T. \& Baker, D.W. (eds.), 2003, Dictionary of the Old Testament, InterVarsity Press, Leicester.

Allen, L., 2008, Jeremiah: A commentary, Westminster John Knox Press, Louisville, KY Arkell, A.J., 1961, A history of Sudan: From the earliest times to 1821, rev. edn., London University Press, London.

Avigad, N., 1986, Hebrew Bible from the time of Jeremiah: Remnants of a burnt archive, Israel Exploration Society, Jerusalem.

Baldwin, J.D., n.d., Pre-historic nations or concerning some of the great peoples and civilizations antiquity and their probable relation to a still older civilization of Ethiopians or Cushites of Arabia, Harper \& Bros. Publisher, New York, NY.

Bailey, R., 1991, 'Beyond the identification: The use of Africans in the Old Testament poetry and narratives', in C.H. Felder (ed.), Stony the road we trod, pp. 165-184, Fortress Press, Minneapolis, MN.

Bluemenbach, J.F., 1865, Anthropological treatise, transl. T. Bendyche, Anthropological Society, London

Breasted, J., 1906, Ancient records of Egypt, vol. 1, University of Chicago Press, Chicago, IL.

Budge, W., 1976, Egyptian Sudan, vol. 1, Arno Press, New York, NY.

Carroll, R.P., 2004, 'The polyphonic Jeremiah', in R.P Carroll \& S. Pickett (eds.), Reading the book of Jeremiah: A search for coherence, pp. 87-98, Eisenbrauns, Winona Lake, IN.

Carroll, R.P., 2008, 'Surplus meaning and the conflict of interpretations: A decade of Jeremiah studies (1984-95)', in A.J. Houser (ed.), Recent research on the Major Prophets, pp. 195-216, Sheffield Phoenix Press, Sheffield.

Chase, R., 2011, Making Jeremiah plain: An Old Testament study guide, Plain and Precious Publisher, Washington, UT.

Copher, C.B., 1985, 'The black man in the biblical world', Journal of the Interdenominational Theological Center 1, 17-16.

De Jong, M.J., 2011, 'Why Jeremiah is not among the prophets: An analysis of the terms היאבנ in the book of Jeremiah', Journal for the Study of the Old Testament 35(4), 483-510.

Diop, A.C., 1974, African origin of civilization: Myth or reality?, transl. M. Cook Lawrence Hill \& Co., Wesport.

Dunston, A., 1974, The black man in the Old Testament and its world, Dorrance \& Co. Philadelphia, PA.

Eissfeldt, O., 1965, The Old Testament: An introduction, transl. P.R. Ackroyd, Harper \& Row Publishers, New York, NY.

Friedrich, G., 1970, Theological dictionary of the New Testament, transl. G.W. Bromiley, Wm B Eerdmans Publishing, Grand Rapids, MI.

Galvin, G., 2011, Egypt as a place of refuge, Mohr Siebeck, Tubingen.

Glatt-Gilad, D., 2000, 'The personal names in Jeremiah as a source for history of the period', Harvard Semitic Monographs 41, 31-45.

Green, J.L., 1971, 'Jeremiah', in C.J. Allen (ed.), Jeremiah-Daniel: The Broadman Bible commentary, vol. 6, pp. 1-202, Broadman Press, Nashville, TN.

Hammershaimb, E., 1970, The book of Amos: A commentary, transl. J. Sturdy, Schocken Books, New York.

Harper, W., 1915, A critical and exegetical commentary on the books of Amos and Hosea: The international critical commentary, ed. C.A Briggs, S.R Driver \& A. Plumer, Charles Scribner \& Sons, New York, NY.

Harris, R.L., Archer, G.A. \& Walke, B.K., 1981, Theological wordbook of the Old Testament, Moody Press, Chicago, IL.

Harrison, K., 1973, Jeremiah and Lamentation, InterVarsity Press, Downers Grove, IL.

Hayes, K.M., 2002, The earth mourns: Prophetic metaphor and oral aesthetic, Brill, Leiden.

Hill, J., 2002, 'The book of Jeremiah MT and early second temple conflicts about prophets and prophecy', Australian Biblical Review 50, 28-42.

Holladay, W.L., 2003, 'The structure and possible setting of the New Covenant passage. Jer. 31, 31-34', in V. Bertomeu (ed.), Palabra, Prodigio, Poesia: in Memoriam P. Luis Alonso Schokel, S.J, pp. 185-189, Pontifical Biblical Institute, Rome. (AnBib 151).

Hyatt, J., 1956, 'The Book of Jeremiah', in G.A. Buttrick (ed.), The interpreter's Bible, vol. 5., pp. 777-1142, Abingdon Press, Nashville, TN.

Jackson, J.G., 1932, Ethiopia and the origin of civilization, Black Classic Press, Baltimore, MD.

Johnstone, R.L., 1973, Religion and society in interaction, Prentice Hall Inc., Englewood Cliffs, NJ.

Keil, C.F., 1950, The book of prophet Jeremiah, transl. J. Martin, Wm B Eerdman Publishing, Grand Rapids, MI.

Keener, C. \& G. Usury, 1996, Black man religion: Can Christianity be Afrocentric? InterVarsity Press, Downers Grove.

King, P., 1993, Jeremiah: An Archaeological Composition, Westminster John Knox Press, Louisville, KY.

Lundbom, J.R., 1999, Jeremiah 1-20, Doubleday, New York.

Maspero, G., [1894] 1968, The dawn of civilization, 2 vols., transl. M.L. McClure, Frederick Ungar Publication Co, New York, NY

Matthews, V., 2012, The Hebrew prophets and their social world, Baker Academic, Grand Rapids, MI. 
McKane, W., 1963, I and II Samuel, SCM Press, London.

McKane, W., 1986, A critical and exegetical commentary on Jeremiah 1-XXV, T\&T Clark, Edinburg.

Muilenburg, J, 1968, 'Form criticism and beyond', Journal of Biblical Literature 88, $1-18$.

Nissinen, M., 2009, 'Historical dilemma of biblical prophetic studies', in H.M. Barstad \& R.G. Kratz, Prophecy in the book of Jeremiah (eds.), pp. 103-110, De Gruyter, New York.

O'Connor, D.,1982, 'Egypt, 1552-664 B.C.', in J.D. Clark (ed.), Cambridge History of Africa, pp. 917-918, Cambridge University Press, Cambridge.

O'Connor, K., 2012, 'Jeremiah', in C.A. Newsom, S.H. Ringe \& J.E. Lapsley (eds.), Women's Bible commentary, pp. 267-271, Westminster John Knox Press, Louisville, KY.

Parke-Taylor, G., 2000, The formation of the book of Jeremiah doublets and recurrent phrases, Society of Biblical Literature Press, Atlanta, GA.

Petersen, D.L., 1998, The Hebrew Bible today, ed. S.L. McKenzie \& M.P. Graham, Westminster John Knox Press, Louisville, KY.

Pritchard, J. (ed.), 1969, Ancient near eastern text relation to the Old Testament, Princeton University Press, Princeton, NJ.

Rawlinson, G., n.d., History of Ancient Egypt, vol. 2, Clarke \& Co, Publishers, Chicago, IL.

Rice, J., 1975, 'Two contemporaries of Jeremiah', Journal of Religious Thought 32, 95-109.

Rogers, J.A., 1982, The real facts about Ethiopia, Black Classic Press, Baltimore, MD.
Sandler, R. Jr., 2006, 'Can a Cushite change his skin? Cushites, racial othering, and the Hebrew Bible', Interpretation 60(4), 401-426.

Sharp, C.J., 2003, Prophecy and ideology in Jeremiah: Struggles in authority in DeutroJeremianic prose, T\&T Clark, London.

Shule, D., 2013, Understanding participant-reference shifts in the book of Jeremiah: A study of exegetical method and its Conseavances for the interpretation of referential incoherence, Brill, Leiden.

Smith, G.A., 1929, Jeremiah, 4th edn., Harper \& Bros., New York.

Stulmann, L., 2011, Abingdon Old Testament commentaries: Jeremiah, Abingdon Press, Nashville, TN.

Thompson, J.A., 1950, Commentary on the prophet Jeremiah and the Lamentations, vol. 4, Wm B Eerdmans Publishing, Grand Rapids, MI.

Thompson, J.A., 1980, The book of Jeremiah, Wm B Eerdmans Publishing, Grand Rapids, MI. (New International Commentary on the Old Testament).

Ullendorf, E., 1968, Ethiopia and the Bible, Oxford University Press, Oxford.

Van den Eynde, S., 2001. 'Taken broken cisterns for the Fountain of Living Water: On the background of metaphor of the whore in Jeremiah', Bibliche Notizen 110, 86-96.

Volney, C.F., 1991, The ruins of empires, Black Classic Press, Baltimore, MD.

Weems, R., 1995, Battered love: Marriage, sex and violence in the Hebrew prophets, Fortress Press, Minneapolis, MN.

Wilson, J., 1951, The culture of Ancient Egypt, University of Chicago Press, Chicago, IL. 